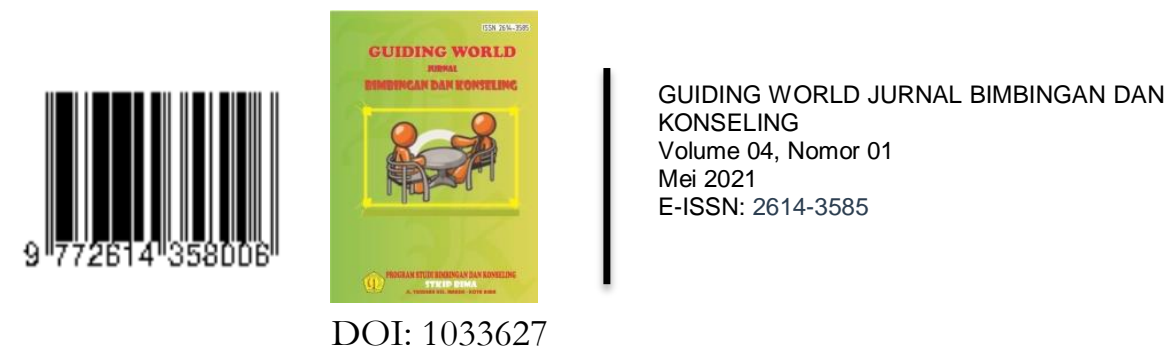

\title{
Analisis Variasi Pembentukan Verba Dalam Bahasa Bima Dan Kontribusinya Bagi Pembelajaran Bahasa Indonesia Di Sekolah
}

\author{
Irham \\ STKIP Bima \\ Irham_bk@stkipbima.ac.id
}

\begin{abstract}
Abstrak: Bahasa Bima (Nggahi Mbojo) merupakan bahasa penutur penduduk asli Bima yang menggunakan simbol-simbol sosial berdasarkan stratifikasi sosial dan tingkatan umur. Sebagai bahasa komunikasi sehari-hari, Nggahi Mbojo digunakan sebagai media dalam interaksi sosial, bahasa transaksi dalam dunia perdagangan, maupun bahasa yang digunakan dalam kegiatan sosial-budaya. Sistem dan kaidah pembentukan variasi verba dalam bahasa Bima tidak banyak berbeda dengan pembentukan variasi verba dalam bahasa daerah lainnya atau dalam bahasa Indonesia, tetapi dalam penggunaannya terdapat perbedaan. Perbedaan ini ditinjau dari pemakaian ragam bahasa yang digunakan oleh penutur bahasa Bima berdasarkan kelas sosialnya dan tingkatan usia sehingga berpengaruh pula pada makna, perilaku, dan bentuk verba dalam kalimat yang diujarkannya. Ditinjau dari segi penggunaannya, bahasa Bima (Nggahi Mbojo) digunakan oleh masyarakat penuturnya berdasarkan ragam bahasa, yaitu: 1) ragam bahasa tinggi (nggahi mangame), yaitu ragam bahasa halus, yang digunakan oleh kelas sosial tertentu kepada kelas sosial lainnya yang lebih tinggi dan tingkatan usia yang lebih muda kepada tingkatan usia yang lebih tua atau dituakan; 2) ragam bahasa rendah (nggahi nginakai), yaitu ragam bahasa sehari-hari, yang digunakan tanpa mengindahkan variasi pilihan kata yang halus, terutama penggunaan variasi kata kerja; dan 3) campur kode, yaitu percampuran ragam bahasa tinggi dan ragam bahasa rendah dalam satu tuturan. Pemakaian ragam bahasa Bima yang mengandung variasi pembentukan verba itu terbentuk berdasarkan faktor-faktor: 1) kelas sosial penutur, 2) usia penutur, 3) usia lawan bicara, 4) situasi pembicaraan, 5) tujuan berbicara, dan 6) bahan pembicaraan
\end{abstract}

Kata Kunci: analisis variasi pembentukan verba; bahasa Bima; pembelajaran bahasa Indonesia 


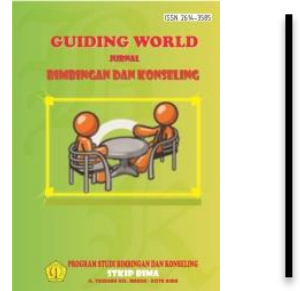

DOI: 1033627

Abstract: The Bima language (Nggahi Mbojo) is the native language of Bima which uses social symbols based on social stratification and age levels. As the language of everyday communication, Nggahi Mbojo is used as a medium in social interaction, the language of transactions in the world of commerce, as well as the language used in socio-cultural activities. The system and rules for forming verb variations in Bima are not much different from those in other regional languages or in Indonesian, but there are differences in their usage. This difference is seen from the use of the variety of languages used by speakers of Bima based on their social class and age level so that it also affects the meaning, behavior, and form of the verbs in the sentences they utter. In terms of usage, the language of Bima (Nggahi Mbojo) is used by the speaking community based on a variety of languages, namely: 1) high language variety (nggahi mangame), which is a variety of subtle language, which is used by certain social classes to other higher and higher social classes. younger age levels to older or older age levels; 2) low language variety (nggahi nginakai), namely the variety of everyday language, which is used without regard to subtle variations in the choice of words, especially the use of verb variations; and 3) mixed code, namely mixing high and low types of language in one speech. Variations in the formation of verbs in the Bima language are based on the use of various Bima languages and their distribution in the proper sentence context. The use of various Bima languages which contain variations in the formation of verbs is formed based on the following factors: 1) the social class of the speaker, 2) the age of the speaker, 3) the age of the interlocutor, 4) the situation of the conversation, 5) the purpose of speaking, and 6) the material of the conversation

Keywords: analysis of variations in verb formation, Bima language, Indonesian language learning

\section{PENDAHULUAN}

Dalam kehidupan manusia, bahasa memegang peran penting sebagai alat komunikasi. Sekalipun seseorang mengenal suatu bahasa (misalnya) tetapi penguasaannya kurang komunikatif tentu tidak memberikan makna. Penguasaan terhadap suatu bahasa merupakan hal yang penting bagi kehidupan manusia. Tanpa bahasa manusia tidak dapat 
berinteraksi dengan lingkungan dan masyarakat sekitar. Bahasa yang digunakan oleh manusia itu diujarkan melalui serangkaian kalimat yang bermakna dan bervariasi dalam komunikasi tulis maupun lisan. Menurut Chaer (2003:249), salah satu unsur variasi dalam penggunaan kalimat bahasa Indonesia yang sering digunakan dalam komunikasi tulis dan lisan adalah variasi verba dalam penggunaan kalimat verbal. Kalimat verbal yang dimaksud di sini adalah kalimat yang dibentuk dari klausa verbal atau kalimat yang predikatnya berupa kata atau frase yang berkategori verba. Sebaliknya, kalimat nonverbal adalah kalimat yang predikatnya bukan kata atau frase verbal: bisa nominal, ajektifa, adverbial, atau juga numeralia.

Berkaitan dengan hal di atas, penelitian mengenai penggunaan atau pembentukan verba lebih banyak dilakukan pada bahasa Indonesia. Padahal dalam bahasa daerah pembentukan dan penggunaan variasi verba lebih menarik untuk diteliti. Sebab, selain variasi pembentukan verbanya ditinjau dari penggunaan ragam bahasa tinggi dan ragam bahasa rendah berdasarkan kedudukan sosial bahasa, juga karena bahasa daerah merupakan bahasa pendukung yang banyak berkontribusi dalam pembentukan bahasa Indonesia.

Bahasa Bima merupakan salah satu bahasa daerah yang ada di Indonesia yang mempunyai sistem dan kaidah-kaidah penggunaannya, termasuk pembentukan dan penggunaan variasi verba dalam kalimat. Sistem dan kaidah variasi pembentukan verba dalam bahasa Bima tidak banyak berbeda dengan variasi pembentukan verba dalam bahasa daerah lainnya atau dalam bahasa Indonesia, tetapi dalam penggunaannya terdapat perbedaan. Perbedaan ini ditinjau dari penggunaan variasi atau ragam bahasa yang digunakan oleh penutur bahasa Bima berdasarkan kelas sosialnya sehingga akan berpengaruh pula pada penggunaan makna, perilaku, dan bentuk verba dalam kalimat yang diujarkannya.

Variasi atau ragam bahasa yang digunakan oleh masyarakat penutur bahasa Bima ini ada yang menggunakan ragam bahasa tinggi dan ada pula yang menggunakan ragam bahasa rendah. Menurut Chaer dan Leonie Agustina (2003:152), ragam bahasa tinggi adalah ragam bahasa yang digunakan pada situasi resmi atau dalam komunikasi resmi, sedangkan ragam bahasa rendah adalah ragam bahasa yang digunakan pada situasi tidak resmi atau dalam suasana santai (akrab). Penggunaan variasi verba dalam komunikasi lisan tersebut digunakan baik dalam situasi resmi maupun dalam situasi yang tidak resmi. Variasi verba yang digunakan dalam kalimat yang diujarkan secara lisan itu terbentuk berdasarkan bentuk, perilaku, dan makna dari pembentukan verba itu sendiri yang didistribusikan dalam kalimat. Dengan demikian, variasi pembentukan verba dalam bahasa Bima ini sangat terkait dengan bentuk, perilaku, dan makna yang terkandung di dalam kalimat. Hal-hal inilah sehingga peneliti tertarik untuk meneliti dan menganalisis variasi pembentukan verba dalam bahasa Bima. Penelitian ini merupakan salah satu bentuk penelitian penggunaan bahasa Bima dalam masyarakat penuturnya sebagai upaya untuk merevitalisasi Nggahi Mbojo (bahasa Bima) yang akhir-akhir ini mulai "tersisihkan" oleh penggunaan bahasa Indonesia dan bahasa asing. Sebagai wujud merevitalisasi Nggahi Mbojo ini yakni dengan cara mengimplementasikannya ke dalam pembelajaran Bahasa Indonesia di sekolah menengah maupun di perguruan tinggi. berikut.

Berdasarkan latar belakang di atas, maka masalah penelitian ini dirumuskan sebagai

- Bagaimanakah variasi pembentukan verba dalam bahasa Bima? 
- Bagaimanakah kontribusi analisis variasi pembentukan verba dalam bahasa Bima bagi pembelajaran Bahasa Indonesia di sekolah?

Tujuan umum penelitian ini adalah mendeskripsikan analisis variasi pembentukan verba dalam bahasa Bima; sedangkan tujuan khusus adalah untuk mengetahui bentuk dan makna variasi pembentukan verba dalam bahasa Bima; dan mendeskripsikan kontribusi analisis variasi pembentukan verba dalam bahasa Bima bagi pembelajaran Bahasa Indonesia di sekolah

\section{METODE}

Pendekatan yang digunakan dalam penelitian ini adalah menggunakan pendekatan empiris. Sebab, gejala-gejala yang akan diteliti telah ada secara wajar, sehingga metode yang sesuai digunakan adalah metode penelitian empiris dengan menggunakan jenis penelitian kualitatif. Penelitian kualitatif ini merupakan upaya untuk mengungkapkan gejala-gejala atau fenomena yang tampak melalui penggambaran data yang ada di lapangan, yaitu dalam hal ini variasi penggunaan verba bahasa Bima.

Penelitian ini berlokasi di wilayah Kota Bima, yaitu di Kelurahan Nitu Kecamatan Raba Kota Bima. Lokasi ini terletak di bagian Tenggara Kota Bima dan berjarak $\pm 12 \mathrm{Km}$ dari pusat pemerintahan Kota Bima serta berada di balik gugusan pegunungan yang membatasi Kota Bima dengan Kabupaten Bima. Lokasi ini dulunya dikategorikan daerah terpencil dalam wilayah Kabupaten Bima sebelum pemekaran dan kemudian masuk ke dalam wilayah administrasi pemerintahan Kota Bima. Pemilihan lokasi penelitian ini berdasarkan pertimbangan bahwa penggunaan bahasa Bima masih murni dari campur kode bahasa Indonesia atau bahasa lainnya. Pertimbangan lain, karena penggunaan verba bahasa Bima yang cukup variatif.

Subyek penelitian dalam penelitian ini adalah sumber data penelitian yang diperoleh di lokasi penelitian. Sumber data penelitian ini yakni penduduk asli Kelurahan Nitu Kecamatan Raba Kota Bima yang berusia di atas 17 tahun (yang sudah memiliki KTP) dan menggunakan bahasa Bima dalam komunikasi sehari-hari. Sumber data penelitian ini terdiri dari berbagai lapisan masyarakat, yaitu petani/buruh, pedagang, pegawai/PNS/guru, pelajar/mahasiswa, dan ibu rumah tangga yang berjumlah 35 orang. Penentuan jumlah responden/informan tersebut menggunakan purpose sampling atau sampel bertujuan untuk memenuhi kebutuhan data penelitian sehingga data penelitian dianggap valid.

Metode pengumpulan data melalui teknik observasi dan perekaman, teknik simak dan catat, dan teknik wawancara (interview). Metode analisis data dalam penelitian ini menggunakan teknik padan. Teknik padan menurut Sudaryanto (1993:21-22) adalah cara menganalisis data yang berupa isi tuturan manusia yang menggunakan referen bahasa; alat penentunya menggunakan teknik pilah unsur penentu atau teknik PUP. Teknik ini bersifat mental yang dimiliki penelitinya yakni sesuai dengan jenis penentu yang akan dibagi-bagi menjadi berbagai unsur dengan daya pilah referen. Dengan demikian, untuk menganalisis variasi pembentukan verba bahasa Bima dilihat dari perbedaan referen atau sosok teracu yang dideskripsikan melalui jenis verba yang digunakan. 


\section{HASIL DAN PEMBAHASAN}

Berdasarkan hasil penelitian dan pembahasan, maka akan dijelaskan tentang: (1) variasi pembentukan verba dalam bahasa Bima, dan (2) kontribusi analisis variasi pembentukan verba dalam bahasa Bima bagi pembelajaran Bahasa Indonesia di sekolah.

Pertama, tentang variasi pembentukan verba dalam bahasa Bima terdiri atas tiga jenis variasi pembentukan verba. Ketiga jenis variasi yang dimaksud, yaitu verba dari segi perilaku semantisnya, verba dari segi perilaku sintaktisnya, dan verba dari segi bentuk morfologisnya. Ketiga jenis variasi pembentukan verba dalam bahasa Bima ini berdasarkan ragam pemakaiannya, yaitu ragam bahasa tinggi (+) dan ragam bahasa rendah (-). (1) Verba dari segi perilaku semantisnya: (a) verba bermakna kegiatan atau perbuatan: ragam bahasa tinggi (+) verba katenggo weki 'makan' pada kalimat santabe katenggo weki wa'u 'silakan makan dulu', ragam bahasa rendah (-) verba ngaha 'makan' pada kalimat mai ngaha wa'u 'mari makan dulu'; ragam bahasa tinggi (+) verba lambe 'ambil' pada kalimat santabe talambe lalompa oi nono ede 'silakan ambil saja air minum itu', ragam bahasa rendah (-) verba weha 'ambil' pada kalimat anae, weha oi nono diru'u ama 'nak, ambil air minum untuk ayah', (b) verba bermakna keadaan atau kejadian: ragam bahasa tinggi (+) verba nggele 'kotor' pada kalimat sarumbuna wunga nggele 'badannya sedang (dalam keadaan) kotor', ragam bahasa rendah (-) verba sampu 'kotor' pada kalimat sarumbuna sampu poda 'badannya kotor sekali'; ragam bahasa tinggi (+) verba kampida 'dibuat jadi kecil/mengecilkan/kecilkan' pada kalimat ama kampidana eli tv baringana eli azan di sigi 'ayah mengecilkan suara tv ketika mendengar suara azan di masjid', ragam bahasa rendah (-) verba kato'i 'dibuat jadi kecil/mengecilkan/kecilkan' pada kalimat anae, kato'i eli tv, dou wunga azan di sigi 'nak, kecilkan suara tv, orang sedang azan di masjid'. (c) verba bermakna pengalaman: ragam bahasa tinggi (+) verba kade'e 'dengar/mende-ngar' pada kalimat mada ntuwu kade'e fitua dou matua 'saya sering mendengar petuah orang tua', ragam bahasa rendah (-) verba ringa 'dengar/mendengar' pada kalimat nahu ntuwu ringa nggahi ra eli dou matua 'saya sering mendengar nasihat orang tua'; ragam bahasa tinggi $(+)$ verba ndonta 'ingat/mengingat' pada kalimat aina ndonta lampa rawi ma ulu 'jangan mengingat kejadian yang dulu', ragam bahasa rendah (-) verba kambeke 'ingat/mengingat' pada kalimat aina kambeke wali sia mawaura lao 'jangan mengingat lagi dia yang telah pergi'. (2) Verba dari segi perilaku sintaktisnya: (a) verba transitif: ragam bahasa tinggi (+) verba kantiri 'meluruskan/memperbaiki menjadi lurus' pada kalimat ama wunga kantiri kuta ma lele 'ayah sedang meluruskan pagar yang miring', ragam bahasa rendah (-) verba karombo 'meluruslkan/memperbaiki menjadi lurus' pada kalimat ama wunga karombona kuta 'bapak sedang meluruskan pagar'; ragam bahasa tinggi (+) verba kanira 'bersihkan/membersihkan' pada kalimat mada wunga kanira almari 'saya sedang membersihkan lemari', ragam bahasa rendah (-) verba karaso 'bersihkan/membersihkan' pada kalimat nahu wunga karaso almari 'saya sedang membersihkan lemari'. (b) verba intransitif: ragam bahasa tinggi (+) verba ndore 'tidur' pada kalimat Ama wunga ndore 'Ayah sedang tidur', ragam 
bahasa rendah (-) verba maru 'tidur' pada kalimat Ari wunga maru 'Adik sedang tidur'; ragam bahasa tinggi $(+)$ verba bonga 'minum' pada kalimat santabe tabonga wa; $u$ kahawata 'silakan diminum kopinya', ragam bahasa rendah (-) verba nono 'minum' pada kalimat nahu nono wa'u 'saya minum dulu'. (c) verba bitransitif: ragam bahasa tinggi (+) verba ngupa wea 'mencarikan' pada kalimat mada ma ngupa wea ariku ru'una 'saya akan mencarikan adikku jodohnya', ragam bahasa rendah (-) verba tio wea 'mencarikan' pada kalimat nahu ma tio wea ariku ru'una 'saya akan mencarikan adikku jodohnya'; ragam bahasa tinggi (+) verba tiwina 'membawakan' pada kalimat Ariku tiwina janga diru'u ompu 'Adikku membawakan ayam untuk kakek', ragam bahasa rendah (-) verba wa'ana 'membawakan' pada kalimat Ina wa'ana tambaku diru'u ama 'Ibu membawakan tembakau untuk ayah'. (3) Verba dari segi bentuk morfologisnya: (a) verba asal: ragam bahasa tinggi (+) verba rempa 'tendang' pada kalimat aina rempa kadera ede! 'jangan tendang kursi itu!', ragam bahasa rendah (-) verba sempa 'tendang' pada kalimat aina sempa edi arimu! 'jangan tendang kaki adikmu!'; ragam bahasa tinggi (+) verba kece 'urut/ pijit' pada kalimat Ina wunga kece edi ama ma ncara 'Ibu sedang pijit kaki ayah yang keseleo', ragam bahasa rendah (-) verba pe'e 'urut/pijit' pada kalimat Ama wunga pe'e edi jara 'Ayah sedang urut kaki kuda'. (b) verba turunan: ragam bahasa tinggi $(+)$ verba (ma)rongga ' (yang)datang' pada kalimat cou marongga akan sangadi? 'siapa yang datang tadi malam?', ragam bahasa rendah (-) verba (ma)mai '(yang) datang' pada kalimat cou mamai peasi? 'siapa yang datang nanti?'; ragam bahasa tinggi (+) verba (ka)nira(na) '(mem)bersih(kan)' pada kalimat Ina wunga kanirana maru kai 'Ibu sedang membersihkan tempat tidur', ragam bahasa rendah (-) verba (ka)raso(na) '(mem)bersih(kan)' pada kalimat Ari wunga karasona uma ndeu 'Adik sedang membersihkan kamar mandi'. (c) verba majemuk: ragam bahasa tinggi (+) verba kamondo mada 'keheranan/merasa heran' pada kalimat Ama kamondo mada ba badena iha farena 'Ayah keheranan setelah tahu padinya rusak', ragam bahasa rendah (-) verba mbora aka 'keheranan/merasa heran' pada kalimat Nahu mbora aka sia loa nuntu 'Saya merasa heran dia bisa bicara'; ragam bahasa tinggi (+) verba mbinta ade 'bahagia' pada kalimat Pape wunga mbinta ade 'Nenek sedang bahagia', ragam bahasa rendah (-) verba neo ade 'bahagia' pada kalimat Nahu wunga neo ade 'Saya sedang bahagia'. (d) idiom: ragam bahasa tinggi (+) verba ne'e midi dei loko 'ingin tinggal dalam perut/melamar/pernyataan lamaran' pada kalimat Mada ne'e midi dei loko ita doho 'Saya ingin melamar putri bapak dan ibu', ragam bahasa rendah (-) verba ne'e maikai 'ingin mendatangi/melamar/pernyataan lamaran' pada kalimat Mada ne'e maikai ana sampela ita doho 'Saya ingin melamar putri bapak dan ibu'; ragam bahasa tinggi (+) verba mabu ntara 'jatuh pamor/terkucilkan' pada kalimat Dou aka waura mabu ntara di ntanda ba dou kampo ake 'orang itu telah terkucikan dalam pandangan orang kampung ini', ragam bahasa rendah (-) verba watidu wara pahuna 'sudah tidak ada muka/terkucilkan' pada kalimat Dou aka watidu wara pahuna di kampo ake 'Orang itu sudah terkucilkan dari kampung ini'. (e) frase verba: ragam bahasa tinggi (+) frase verba wunga ndore 'sedang tidur' pada kalimat Ina wunga ndore 'Ibu sedang tidur', ragam bahasa rendah (-) frase verba wunga maru 'sedang tidur' pada kalimat Ari wunga maru 'Adik sedang tidur'.

Dengan demikian, ditinjau dari segi penggunaannya, maka Nggahi Mbojo digunakan oleh masyarakat penuturnya berdasarkan ragam bahasa, yaitu: 1) ragam 
bahasa tinggi (nggahi mangame), merupakan ragam bahasa halus yang digunakan oleh kelas sosial tertentu kepada kelas sosial lainnya yang lebih tinggi atau tingkatan usia yang lebih muda kepada tingkatan usia yang lebih tua (dituakan); 2) ragam bahasa rendah (nggahi nginakai) merupakan ragam bahasa sehari-hari, yang digunakan tanpa mengindahkan variasi pilihan kata yang halus, terutama penggunaan variasi kata kerja; dan 3) campur kode, yaitu percampuran ragam bahasa tinggi dan ragam bahasa rendah dalam satu tuturan. Faktor-faktor yang mempengaruhi variasi pembentukan verba dalam bahasa Bima, yaitu: 1) kelas sosial penutur, yaitu tingkatan sosial penutur: apakah di atas tingkatan sosial penutur, sepantar, atau di bawah tingkatan sosial penutur; 2) usia penutur, yaitu tingkatan usia/umur dari penutur: apakah lebih tua, sepantar, atau lebih muda dari usia penutur; 3) usia lawan bicara, yaitu tingkatan usia/umur lawan bicara: apakah lebih tua, sepantar, atau lebih muda dari usia lawan bicara; 4) situasi pembicaraan, yaitu dalam konteks pembicaraan resmi atau tidak resmi; 5) tujuan berbicara, yaitu bertujuan untuk mendidik, menginformasikan, mempengaruhi, atau menghibur; dan 6) bahan pembicaraan, yaitu persoalan yang dikemukakan dalam pembicaraan: apakah serius dan resmi atau santai dan tidak resmi.

Kedua, tentang kontribusi analisis variasi pembentukan verba dalam bahasa Bima bagi pembelajaran Bahasa Indonesia di sekolah. Hasil analisis variasi pembentukan verba dalam bahasa Bima ini dapat dikontribusikan bagi pembelajaran Bahasa Indonesia di sekolah pada aspek pembelajaran tata bahasa: tata bunyi (fonologi), tata bentuk (morfologi), tata kalimat (sintaksis), dan tata makna (semantik); aspek berkomunikasi; aspek kesantunan berbahasa; dan aspek nilai-nilai budaya. Aspek berkomunikasi mencakup tentang siapa yang berbicara dan siapa lawan bicara, situasi pembicaraan, tujuan berbicara, dan bahan pembicaraan. Aspek kesantunan berbahasa dideskripsikan melalui pernyataan yang menunjukkan sikap penghormatan terhadap lawan bicara melalui pilihan kata kerja (verba) yang tepat dalam rangkaian kalimat yang tepat pula. Aspek nilai-nilai budaya dideskripsikan melalui penggunaan bahasa daerah (dalam hal ini bahasa Bima) dalam komunikasi sosial kemasyarakatan sebagai warisan budaya yang di dalamnya terkandung kearifan lokal bagi masyarakat penuturnya

\section{PENUTUP}

a. Bahasa Bima (Nggahi Mbojo) merupakan bahasa penutur penduduk asli Bima yang menggunakan simbol-simbol sosial berdasarkan stratifikasi sosial dan tingkatan umur. Ditinjau dari segi penggunaannya, maka bahasa Bima (Nggahi Mbojo) digunakan oleh masyarakat penuturnya berdasarkan ragam bahasa tinggi (nggahi mangame) yakni ragam bahasa halus, yang digunakan oleh kelas sosial tertentu kepada kelas sosial lainnya yang lebih tinggi atau tingkatan usia yang lebih muda kepada tingkatan usia yang lebih tua (dituakan) dan ragam bahasa rendah (nggahi nginakai) yakni ragam bahasa sehari-hari, yang digunakan tanpa mengindahkan variasi pilihan kata yang halus, terutama penggunaan variasi kata kerja serta campur kode yakni percampuran ragam bahasa tinggi dan ragam bahasa rendah dalam satu tuturan. Variasi pembentukan verba dalam bahasa Bima berdasarkan pemakaian ragam bahasa Bima dan pendistribusiannya dalam konteks kalimat yang tepat. Variasi pembentukan verba tersebut terbentuk berdasarkan faktor-faktor:: a) kelas sosial penutur, b) usia 

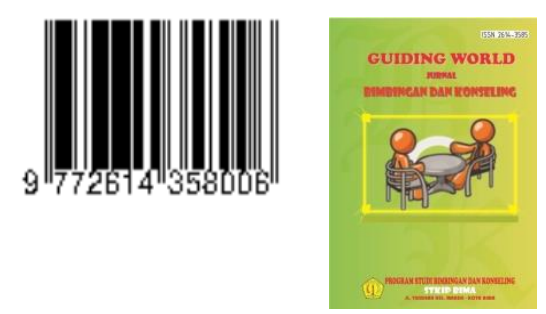

penutur, c) usia lawan bicara, d) situasi pembicaraan, e) tujuan berbicara, dan 6) bahan pembicaraan.

b. Aspek-aspek yang dapat dikontribusikan bagi pembelajaran Bahasa Indonesia di sekolah, yaitu pada aspek pembelajaran tata bahasa, aspek berkomunikasi, aspek kesantunan berbahasa, dan aspek nilai-nilai budaya

\section{DAFTAR PUSTAKA}

Alwi, Hasan, Soenjono Dardjowidjojo, Hans Lapoliwa, dan Anton M. Moeliono. 2003. Tata Bahasa Baku Bahasa Indonesia. Jakarta: Balai Pustaka.

Alwi, Muhammad Tahir. 2003. Kamus Bima Indonesia Inggris. Mataram: Karsa Mandiri Utama.

Alwasilah, A. Chaedar. 1993. Linguistik Suatu Pengantar. Bandung: Angkasa.

Arikunto, Suharsimi. 1997. Prosedur Penelitian Suatu Pendekatan Praktek. Jakarta: PT. Rineka Cipta.

Chaer, Abdul. 2003. Linguistik Umum. Jakarta: PT. Rineka Cipta.

Chaer, Abdul dan Leonie Agustina. 2003. Sosiolinguistik Suatu Pengantar. Jakarta: Rineka Cipta.

Djajasudarma, T. Fatimah. 1999. Semantik 1: Pengantar Ke Arah Ilmu Makna. Bandung: PT. Refika Aditama.

Halliday, M.A.K, \& R. Hasan. 1989. Language, context, and text: Aspects of language in a social-semiotic perspective. Victoria: Deakin University.

Moeliono, Anton, dkk. 1999. Tata Bahasa Baku Bahasa Indonesia. Jakarta: Balai Pustaka.

Moleong, Lexy J. 2000. Metodologi Penelitian Kualitatif. Bandung : PT. Remaja Rosdakarya.

Nawawi, Hadari. 1991. Metode Penelitian Bidang Sosial, Cetakan Kelima. Yogyakarta: Gadjah Mada University Press.

Ramlan, M. 1985. Morfologi Suatu Tinjauan Deskriptif. Yogyakarta: CV. Karyono.

Ratna, Ny.K. 2010. Metodologi Penelitian: Kajian Budaya dan Ilmu Sosial Humaniora pada Umumnya. Yogyakarta: Pustaka Pelajar.

Samsuri. 1987. Analisis Bahasa. Jakarta: Erlangga.

Saussure, F.D. 1916. Pengantar Linguistik Umum. Diterjemahkan oleh Rahayu Hidayat, dari buku Cours de Linguistique Generale. 1988. Yogyakarta: Gajah Mada University Press.

Subroto, E.D. 2007. Pengantar Metode Penelitian Linguistik Struktural. Surakarta: UNS Press.

Sudaryanto, dkk. 1993. Metode dan Aneka Teknik Analisis Bahasa: Pengantar Penelitian Wahana Kebudayaan Secara Linguistik. Yogyakarta: Duta Wacana University Press.

Sutopo, H.B. 2002. Metodologi Penelitian Kualitatif. Surakarta: Sebelas Maret University Press.

Tarigan, Henry Guntur. 1984. Sintaksis. Bandung: Angkasa.

Verhaar, J.W.M. 2006, Cet. Kelima. Asas-asas Linguistik Umum. Yogyakarta: Gadjah Mada University Press. 